\title{
Visual literacy of the deaf for science teaching
}

\author{
Wanderson Cleyton da Silva ${ }^{1 *}$; Shirleide Maria de Oliveira ${ }^{2}$; Bárbara Rafaela da Silva Dias ${ }^{3}$; Juliana \\ Georgia da Silva ${ }^{4}$; Ana Jhoice de Santana Ferreira ${ }^{5}$; Polyane Maria da Silva ${ }^{6}$; Bruna Iasmim dos \\ Santos Pompéia ${ }^{7}$; Diego Filipe da Silva ${ }^{8}$; Weslainy Margarida da Silva ${ }^{9}$; Adla Polayne Barbosa da \\ Silva $^{10}$; Juceli Gomes de Queiroz ${ }^{11}$; Marcos Vinícius Alves da Silva ${ }^{12}$
}

1 Student of the Biology course at University Center of Vitória de Santo Antão - UNIVISA.

2 Specialization in the teaching of Mathematical at AEMASUL.

3 Graduating in full degree in biological sciences from the University Center of Vitória de Santo Antão - UNIVISA.

4 Undergraduate degree in biological sciences from the Federal University of Pernambuco, Academic Center of Vitória.

5 Master's students at the graduate program in Morpho Technology at Federal University of Pernambuco (UFPE)

6 - 9 Undergraduate degree in biological sciences from the Federal University of Pernambuco, Academic Center of Vitória.

10 Graduating in full degree in biological sciences from the University Center of Vitória de Santo Antão - UNIVISA.

11 Postgraduate Course of Methodology of Teaching Biological Sciences at Leonardo Da Vinci University Center - UNIASSELVI.

E-mail adresses: professorwanderson2201@gmail.com (Wanderson Cleyton da Silva), shirleideoliver@outlook.com (Shirleide Maria de Oliveira), barbararafaeladias@hotmail.com (Bárbara Rafaela da Silva Dias), juliana.georgia@ufpe.br (Juliana Georgia da Silva), jhoiceferreira15@gmail.com (Ana Jhoice de Santana Ferreira),polyane.maria@ufpe.br(Polyane Maria da Silva), bruna.iasmim@ufpe.br (Bruna Iasmim dos Santos Pompéia), diego.felipesilva@ufpe.br (Diego Filipe da Silva), weslainysilva56@gmail.com (Weslainy Margarida da Silva), adlapbs@gmail.com (Adla Polayne Barbosa da Silva), Juceligomes1995@gmail.com (Juceli Gomes de Queiroz), vinicius201653@gmail.com (Marcos Vinícius Alves da Silva).

${ }^{*}$ Corresponding author

\section{To cite this article:}

Silva, W.C.; Oliveira, S.M.; Dias, B.R.S.; Silva, J.G.; Ferreira, A.J.S.; Silva, P.M.; Pompéia, B.I.S.; Silva, D.F.; Silva, W.M.; Silva, A.P.B.; Queiroz, J.G.; Silva, M.V.A. Visual literacy of the deaf for science teaching. International Journal of Sciences. Vol. 2, No. 3, 2021, pp. 4544. ISSN 2763-5392.

Received: 10 09, 2021; Accepted: 10 10, 2021; Published: 11 03, 2021

\begin{abstract}
When a child is inserted in school, it becomes literate with letters and numbers, which later serve as the basis for the construction of words and texts. Visual literacy helps the child to be literate at first in his/her language: pounds (Brazilian sign language) for soon after learning a new language. With interactive practices and effective methodologies, visual literacy in science teaching has suffered a great scarcity, due to the lack of visual materials signaled from some programmed content, due to this need for resources the teacher has seen this as a great challenge. As a key of this transformation process, adopting other resources to help in their classes, but some students feel the need for interpretation in some concepts, because they have not been literate in sign language. It is essential, therefore, to conduct an investigation on how to produce and/or adapt materials/resources making accessible and establishing guidelines in the realization of a new conception of teaching learning aimed at deaf students. This paper seeks to know practices that can serve as instruments for deaf students. To understand how these resources can adapt in the school context, this study sought to understand what visual literacy is in an inclusive and large-scale perspective and how these resources emerge and strengthen in communication accessibility. Therefore, the importance of reviewing articles, books and magazines that address the theme studied and also the linguistic context that involves the process of teaching and learning the student with deafness in the discipline of science, this one, takes place in his first language (Libras) and this device matters to changes in concepts and roles within the educational environment aimed at a bilingual proposal, in which students, educators and managers are main actors in decision-making aimed at true social and school inclusion.
\end{abstract}

Keywords: Literacy. Teaching. Deaf education. 
2 Silva, W.C.; Oliveira, S.M.; Dias, B.R.S.; Silva, J.G.; Ferreira, A.J.S.; Silva, P.M.; Pompéia, B.I.S.; Silva, D.F.; Silva, W.M.; Silva, A.P.B.; Queiroz, J.G.; Silva, M.V.A. Visual literacy of the deaf for science teaching...

\section{Introduction}

Visual literacy allows the individual to understand, see and share what a given image means, but in order for this to be used, requires the individual to overcome previous obstacles, such as a late entry into school, which result in the visual capacity of the human being, in addition to this characteristic the individual in turn has the ability through his intuitions to program himself to be able to give visual decisions, giving preferences to your personal tastes, wills and desires (DONDIS, 2007).

According to Kleiman, visual literacy is a set of collective practices that use symbols and writings following a very specific framework. There is a great utility of the student's interaction with the social environment in which he is inserted, where literacy is a fundamental key for this process of socialization to occur. However, it is noted that the emphasis on research is usually on writing, while literacy is not valid or inserted in these studies, deselecting any participation in the development of students.

For a science teacher, the important tool to help his classes are didactic models, models that serve as a very important instrument in the construction of knowledge of the subjects that were previously taught in the classroom, aiming at the search for knowledge and programmed contents (PAVANI; FONTANA, 2009);

For an interaction between the deaf student and the contents experienced, the teacher then emerges as a mediator following adapter materials and methods, effectively using technology to promote well-being and better use, so there are great questions such as what mobilizes this study: is visual literacy in science teaching contemplated in school?

In this work, we are committed to respond briefly, through bibliographic research of a qualitative nature, to this concern and, to this end, we discuss visual literacy in the teaching of sciences, methods that help in the interaction of contents programmed for science. Finally, we argue that visual literacy already brings to the centrality to the issues in question, but in school inclusion, sometimes in the name of "equality", deaf students are forgotten, hindering and preventing the opportunities that accompany other colleagues without any kind of discrimination.

The objective of this work is to present visual literacy for the deaf, demonstrating the strategies used in science teaching.

\section{Methodology}

For the development of this bibliographic study, we searched for papers available in the Scientific Electronic Library Online (SciELO) platform and in journals of the Coordination for the Improvement of Higher Education Personnel (CAPES), which address the theme studied and also the linguistic context that involves the process of visual literacy for deaf children.

The descriptive research method was used in order to analyze the need for visual literacy for the deaf in science teaching, starting from a bibliographic review composed of the main articles in the area.

In the course of this study, 16 studies were found on the research platform. As empirical objects, three articles were selected because the themes are approximated to the theme under study, were written in Portuguese and were published between the years 2012 to 2019 .

\section{Results and Discussion}

\subsection{Visual literacy}

Reading and writing practices can be understood as literacy according to socio-communicative contexts. This is where literacy and this ability to use language appear imbricated (KLEIMAN, 2005; SOARES, 2010).

In this perspective, literacy is something that causes changes in the social practices and social reality of the speakers (SOARES, 2011). When, however, these speakers are deaf subjects, literacy needs to take place in the Brazilian sign language. This is possible when visual literacy is the teacher's first pedagogical approach.

In this work, visual literacy is understood as the ability to read, interpret information presented through nonverbal texts, images, graphs and, in general, forms that enhance communication skills (STOKES, 2002).

Rocha (2008), in turn, states that visual literacy is the development of the composition of image reading in social practices. This assertion is ratified by Santaella (2012) by stating that visual literacy is the learning of reading images, of the ability to observe its aspects constitutive traits, of careful identification of what is produced inside each image.

\subsection{Visual literacy for the deaf}

Visual language is culturally constituted and specific, so it reveals aspects of culture and deaf community (QUADROS, 2006). For this reason, we argue that visual literacy is promising in the learning teaching process and is the itinerary that can contribute to science teaching. One of the challenges in teaching this discipline to the deaf is the lack of signs in pounds that represent and describe or present scientific concepts.

On this theme Amorim (2004) states that scientific knowledge receives new identities for the way they are worked in school daily life, and for this reason we believe that if the science teacher prioritizes visual literacy, he is bringing meanings and meanings to his pedagogical practice. It is worth remembering, therefore, that education in natural sciences from the point of view of the school context presupposes the joint construction of knowledge, if the teacher has a perspective of inclusive and inclusive teaching.

\subsection{How to promote visual literacy for these students?}

As for the visual resource, as a way to facilitate technological access promoting a good preparation regardless of the chosen medium, whether digital or material, brings in a practical way a more coherent conception in the 
virtual field for a form of learning teaching, within these different resources (SANTOS, 2009).

Oliveira (2008), states that the visual has become a great highlight for the interpretation of texts, which was once just a simple nonverbal text, today becomes an effective pedagogical possibility, gaining a large proportion, transforming a reality based on a specific communication pattern.

\subsection{What strategies/resources of visual literacy can be used in science teaching?}

According to Maluf (2006), the use of games and games in a pedagogical way arouses a great curiosity in students to learn by expanding an interrelation of the contents experienced in the learning teaching process.

The playful can be employed in science teaching regardless of the student's age group. The "ludicity" promotes dynamism in the class, enabling the student a harmonious relationship with the contents experienced. In search of new resources, the teacher needs to think of several ways to favor the student in the correlation and improvement of different concepts prevailing in the classroom. In this sense, the teacher needs to understand the need for learning of each student (CAMPOS, 2008).

A discipline cannot be developed only in a theoretical way but supported by a set of practical classes that contribute to improving knowledge. However, in most schools there is a scarcity of biological material for practical classes and didactic models can be one of the tools adopted to fill this gap. (MATOS et al,.2009).

When such content is worked in the classroom, students feel a greater need to have a complement to the theme experienced, however, whether in game format, teaching models and even in practical classes, this teaching strategy serves so that the student can take away their necessary doubts in a dynamic way, improving the improvement of learning, these strategies are necessary to meet the need to repair the faults encountered throughout these circumstances.

In the universe of studies developed, we will present, briefly, how some authors approach the theme under study. Langhi and Nardi (2012) affirm in their article that the different ways that the contents experienced in the science discipline can be approached arouses the curiosity of the deaf student in being able to relate his day to day, interacting in various areas, triggering interdisciplinarity. They also emphasize that the teacher should consider the capacity that the individual has and seek to arouse curiosity and imagination, enabling numerous learning opportunities.

In another study, Moreira (2015) states that when students deaf or with some hearing problems are exposed to collective work, they begin to demonstrate a socialization resulting from a positive transformation, resulting in the construction and development of their potential, awakening in themselves the need to stimulate skills in the learning process.

Bellotti (2017) states that there is a greater need for the teacher to have an approximation with the deaf student and says that for this it is enough that the teacher has a basic knowledge of the Brazilian sign language (pounds). The teacher does not need to be an interpreter of the language, but, at the very least, he should contextualize his classes by applying an alternative methodology for the inclusion of this student.

However, we know that this is still a long way to go in that there is a great need for visual resources for science teaching. The teacher needs to use resources that can fill the lack of visual material, resulting from the scarcity of the use of images and their signs in pounds, but in return the use of manual resources brings the playful to the classroom.

\section{Conclusions}

Throughout this literature review on visual literacy for the deaf in science teaching, we infer the importance of resources and teaching materials for an adaptation of the development of the deaf student, breaking a barrier that delimits the learning of the deaf child.

The adaptation of methodological resources and preparation of teaching materials to supply the need for visual material and signage brings to the teacher a diversified way of working its content with the deaf child. These strategies result in the improvement of teaching and learning and interaction with the other colleagues present there.

Finally, it is also worth remembering that the deaf student has the right to enjoy his language and have it as a pedagogical process and for this purpose should be used strategies that are in accordance with visual pedagogy.

In this perspective, what can be concluded is that the use of images and signs in contents in the science discipline is still scarce, causing the teacher to adopt other methods and resources to go through the curricular matrix together with the deaf student, but the resource adopted is not always very effective, for this reason visual literacy is the necessary tool in the formation of this individual.

\section{References}

[1] AMORIM, A. C. Photografias, escritas cotidiano e currículo de formação. In: FERRAÇO, Carlos Eduardo (org). Cotidiano escolar, formação de professores (as) e currículo. São Paulo: Cortez, 2005.

[2] BISCH, S. M. Astronomia no Ensino Fundamental: Natureza e conteúdo do conhecimento de estudantes e professores. Universidade de São Paulo - USP, (Doutorado em Educação; orientadora: Profa. Dr. Yassuko Hosoume). São Paulo: USP, 1998. Disponível em:

http://www.btdea.ufscar.br/arquivos/td/1998_BISCH_T _USP.pdf Acesso em: 23 nov. 2017.

[3] CAMPOS, L.M.L; BORTOLOTO, T.M.; FELICIO, A.K.C. A produção de jogos didáticos para o ensino de ciências e biologia: uma proposta para favorecer a aprendizagem. 2008. Disponível em: 
4 Silva, W.C.; Oliveira, S.M.; Dias, B.R.S.; Silva, J.G.; Ferreira, A.J.S.; Silva, P.M.; Pompéia, B.I.S.; Silva, D.F.; Silva, W.M.; Silva, A.P.B.; Queiroz, J.G.; Silva, M.V.A. Visual literacy of the deaf for science teaching...

$<$ http://www.unesp.br/prograd/PDFNE2002/aproducaod ejogos.pdf. Acesso em 25 jun. 2008.

[4] DONDIS, Donis A. Sintaxe da linguagem visual. São Paulo: Martins Fontes, 2007.

[5] GESUELI, Z.M. \& MOURA, L. de. Letramento e Surdez: a visualização das palavras. In: ETD - Educação Temática Digital. Campinas, v.7, n.2, p.110-122, jun. 2006. pp 110-122.

[6] KLEIMAN, Ângela. Os significados do letramento: uma perspectiva sobre a prática social da escrita. Campinas: Mercado de letras, 1995.

[7] LANGHI, R.; NARDI, R. Educação em Astronomia: repensando a formação de professores. Educação para a Ciência, vol. 11. São Paulo: Escrituras, 2012

[8] MACEDO, L; PETTY, A.L.S.; PASSOS, N.C. Aprender com jogos e situações-problema. Porto Alegre: Artmed, 2000.

[9] MALUF, A.C.M. Atividades lúdicas como estratégias de ensino aprendizagem. 2006. Disponível em: http://www.psicopedagogia.com.br/artigos/artigo.asp?en trID=850 Acesso em: 17 de outubro de 2009.

[10] MATOS, Cláudia; OLIVEIRA, Carlos Romero; SANTOS, Maria Patrícia; FERRAZ, Célia. Utilização de Modelos Didáticos no Ensino de Entomologia. REVISTA DE BIOLOGIA E CIÊNCIAS DA TERRA. Vol. 09, no 01. Paraíba, 2009. Disponível em: < http://eduep.uepb.edu.br/rbct/sumarios/pdf/3matos.pdf $>$ Acesso em 09/11/2012.

[11] MORAN, J. M.; MASETTO, T.; BEHRENS, M. A. Novas tecnologias e mediação pedagógica. Campinas, SP: Papirus, 2013.

[12] MOREIRA, M. A. Teorias de aprendizagem. São Paulo: E.P.U, 2015.

[13] OLIVEIRA, S., Texto visual, estereótipos de gênero e o livro didático de língua estrangeira. Trab. Ling. Aplic., Campinas, 47(1): 91-117,2006

[14] PAVIANI, Neires Maria Soldatelli. FONTANA, Niura Maria. Oficinas pedagógicas: relato de uma experiência. Conjectura, v. 14, n. 2, 2009.

[15] QUADROS, R. M.; SCHMIEDT, M. L. P. Ideias para ensinar português para alunos surdos. Brasília: MEC, SEESP, 2006.

[16] ROCHA F. Monografia "Imagem e palavra: a produção literária para crianças em livros das autoras/ilustradoras Ângela Lago e Eva Furnari “, realizada como trabalho de conclusão de curso de curso de graduação em Pedagogia pela Universidade Federal de Minas Gerais. (UFMG 2008)

[17] ROCHA, H. A. B. O lugar da linguagem no ensino de história: entre a oralidade e a escrita.2006. Tese (Doutorado em Educação) - Universidade Federal Fluminense, Niterói, Rio de Janeiro.

[18] SANTAELLA, L.; NÖTH, W. Imagem: cognição, semiótica e mídia. São Paulo: Iluminuras, 2012.
[19] SANTOS, B. S. Um Discurso sobre as Ciências. Porto: Edições Afrontamento. 6a Edição. São Paulo: Cortez. 2009.

[20] SOARES, Magda. Letramento e escolarização. In: Letramento no Brasil, reflexões a partir do INAF 2001 (org.) Vera Massagão Ribeiro - 2a Ed. - São Paulo, global, 2004

[21] SOARES, Magda. Letramento e alfabetização: as muitas facetas. Revista brasileira de educação, Rio de Janeiro: n. 25, p. 5-17, 2004

[22] SOARES, Magda. Novas Práticas de Leitura e Escrita: Letramento na Cibercultura. Educ. Soc., Campinas, vol. 23, n. 81, p. 143-160, 2002

[23] STOKES, S. Visual literacy in teaching and learning: A literature perspective. Electronic Journal for the Integration of Technology in Education, v.1, n.1, 2002

[24] VAlENTE T., COSTA, A. R. A, OLIVEIRA, M. G.; TAVARES, R. F. e SOUZA, T. M. F. A Contribuição do Lúdico no Processo de Ensino- Aprendizagem. Tempo \& Ciência, Revista do Centro Universitário Luterano de Manaus Número 11/12 - 2004/2005. 